\title{
各種内科疾患に扮忛る白血球㠜集素について
}

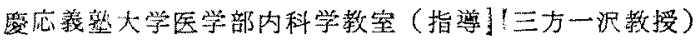

高橋隆一

\section{LEUKOAGGLUTININS IN VARIOUS INTERNAL DISEASES}

BY

\author{
Ryuichi Takahashi \\ Department of Internal Medicine, \\ School of Medicine, Keio University \\ (Prof.: I. Mikata)
}

\begin{abstract}
梗概 木村の重層遠心分離法によつて純粹に分離した白血球を使用し，100例の諸内科疾患について Ddusset 法により白血球凝集素を檢甞した．11例（11\%）に陽性を認めたが，輸血の影響を檢討す る目的で輸血, 非輸血 2 群に分けて检討した. その結果, 陽性例注明ら尔に輸血群に多く, しかも輸 血量方多い程陽性率の高くなる㑯向のあることを知つた. 又從来陽性例の報告のない胃漬瘍, 胃癌, 潰演性大腸炎, 慢性腎炎の 4 疾患に陽性例定認めたが，いずれも輸血例であり，輸血による同種抗体 と考元られる. 非輸血陽性例では, 白血球減少を認めたが, 輸血陽性例では不定であつた。
\end{abstract}

近年血夜学の分野において免疫血液学の発展に はめざましいものがあり，従来原因不明とされて いた一群の血液疾患に種々の抗体が証明され，そ の病因が先疫学的に説明される様になつた。しか し，最近までその研究対象は赤血球のみであつ た.赤血球以外の血液成分に対する自家抗体の証 明は，1951年 Harrington 等による抗血小板抗体 の証明が初かてであるが，抗白血球抗体も同1951 年に Moeschlin1)により証明された。すなわち， ピラミドンによる顆粒球減少症患者の血清が， 白血球を凝集し，健康人に患者血液を輸血すると 一時的に顆䊀球減少をおこすことを認め，㭧者血 清中に抗白血球抗体の存在することを明らかにし た. その後白血球凝集試験の術式 ${ }^{233)}$ が確立され て，白血球凝集素の性質が明らかにされると共に， 白血球減少寺示諸疾患についてその梌索が行な われた。その結果, 顆粒球減少症の他に, ビール 又性肺炎，伝染性単梌症，発作性夜間血色素尿 症，白血病，播程性紅玟性狼侷，脾結核等に它
血球凝集素が証明されだ。しかし，今日ではこれ らの疾患に証明された白血球凝集素の一部が，自 家抗体ではなく輸血による同種抗体であろうとす る批判的研究も報告されつつある。

私は，血液疾㭧を主とする各種内科疾患100例 について白血球凝集素を检索し，従来報告のない 三，三の疾患に陽性例を認め，そのいずれも多量 輸血例である点から, 陽性率之輸血の有無, 量に 関して若干の知見を得たのでここに報告する。

\section{I 検查方法}

従来広く行なわれているのは, Dausset 法2) であるが，本法による血球浮遊液を使用する と，かなりの赤血球が混在して白血球凝集の判定 上支障をきたすことが少なくない，そのため白血 球分離には，木村の重層遠心分離法4を採用して より純粋に分離し，その後 Dausset 法にならつ て凝集の有無を検查した。

a) 白血球分離法

被検血液とA BO同型の健康者方ら静脈血 $50 \mathrm{cc}$ 
を採血し，小ガラス球約10コを入れたエルレンマ イヤーのフランスコで脱線維を行ない, 大型遠沈 管にて 2,500r.p.m. 20分間遠沈する. その後血 球成分の最上部にある白血球層（buffy coat） ピペットで採り，生理的食塩水で 2 倍に稀鄱し， 試料とする。

一方pH 7.4, 比重 $1.068 \sim 1.070 （ 15^{\circ} \mathrm{Cにおい}$ て)のアラビヤゴム溶液を調製する，私の経験で

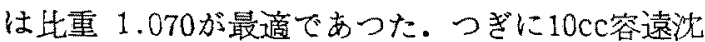

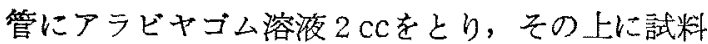
䄪 $3 \mathrm{cc}$ 静加に重層し, Spinco 型超遠心分離器 で 8,000r.p.m. 15分間遠沈すると白血球部分の みがアラビヤゴム溶液の界面上に浮上し，赤血球 は管底に沈澱する．白血球部分のみをピペットで 採り, 生理的食塩水に浮遊し軽く遠沈して白血球 を得る。それを約 2 倍に稀釈し，凝集試験に使用 する.本法によると白血球 100 コに刘し，赤血球 1〜3コを混在するにすぎない。

b）白血球凝集試験

被検血清を $56^{\circ} \mathrm{C} ， 30$ 分不活化し，その 2 滴を白 血球浮遊夜 1 滴と共に小試験管（内径 $0.7 \sim 0.8$ $\mathrm{cm})$ に入れて混合し， $37^{\circ} \mathrm{C} ， 1$ 時間放置する。そ の後管内容を軽くふつてからスライドに移し，力

Fig. 1
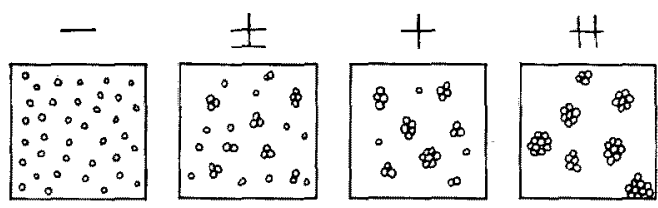

バーグラスをかけて鏡兌 $(30 \times)$ し，凝集の有無 を判定した。位相美顕微鏡を使用すると判定は容 易である。なお赤血球を混在しないので $1 \%$ 醋酸 を加える必要はない，判定基準はFig.1亿示す ごとくで，十，十を陽性としな。なお，白血球浮 遊液に不活化しない血清，生理的食塩水をそれぞ れ加えて詨照とし，各検体については少なくとも 2 回以凝集を調べた。

\section{II 成 績}

Table 1 に示すごとく，血液疾患を主とする
Table 1. Groups of Diseases investigated of Leukoagglutinins

\begin{tabular}{l|c}
\multicolumn{1}{c|}{$\begin{array}{c}\text { Groups of Diseases } \\
\text { Investigated }\end{array}$} & $\begin{array}{c}\text { Number of } \\
\text { Patients. } \\
\text { Examined }\end{array}$ \\
\hline Blood disorders & 76 \\
\hline Collagen diseases & 6 \\
\hline Malignant neoplasms & 6 \\
\hline $\begin{array}{l}\text { Disorders of the gastroint. } \\
\text { tract }\end{array}$ & 3 \\
\hline Renal diseases & 4 \\
\hline Miscellaneous & 5 \\
\hline \multicolumn{1}{c}{ Total }
\end{tabular}

Table 2. Patients with Leukoagglutinins

\begin{tabular}{l|c|c}
\hline \multicolumn{1}{c|}{ Diseases } & $\begin{array}{c}\text { Volume of } \\
\text { Transf. } \\
\text { Blood }\end{array}$ & $\begin{array}{c}\text { Leucocytes } \\
\text { Count }\end{array}$ \\
\hline acut. myelo. Leuk. & 7600 & 11800 \\
\hline acut. myelo. Leuk. & 9000 & 1800 \\
\hline chron. myelo. Leuk. & 3800 & 9800 \\
\hline I.T.P. & 3500 & 3000 \\
\hline S.L.E. & 0 & 3600 \\
\hline S.L.E. & 1800 & 5400 \\
\hline malig. Lymphom & 0 & 4000 \\
\hline Cancer of the Stomach & 5200 & 4200 \\
\hline gastric ulcer & 4500 & 5100 \\
\hline ulcerative Colitis & 3000 & 5600 \\
\hline chron. Nephritis & 4400 & 3900 \\
\hline
\end{tabular}

各種内科疾患 100例について検索した。

a) 各種疾㭧別の成績

陽性例は 100例中11例（11\%）に認めたが，そ の内訳疾患別に述べる。

i）血液疾㭧

急性骨髄性白血病14例中 2 例に陽性を認めた。 いずれも大量軨血例で，それぞれ $7,600 \mathrm{cc} ， 9,000$ ccの輸血を受けている。後者は入院時すでに輸血 （量不明）を受けていたが当時は陰性，その後瀕 回の輸血を受けている間に陽性となり，プレド ニソロン大量使用中にもかつわらず8力月後死亡 する迄每回陽性であつた。慢性白血病 4 例中 1 例 に陽性を認めたが， 3,800ccの輸血を受けてい る. 血小板減少性紫斑病 4 例中 1 例に陽性艺認め たが，輸血前陰性，3,500cc輸血後陽性となり， プレドニソロン使用中にもかかからず 1 力月後の 
Table 3. Relation between Blood Transfusions and Leukoagglutinins

\begin{tabular}{c|c|c|c}
$\begin{array}{c}\text { Blood } \\
\text { Transfusion }\end{array}$ & $\begin{array}{c}\text { No. } \\
\text { Patients }\end{array}$ & $\begin{array}{c}\text { Without } \\
\text { Leukoagg1. }\end{array}$ & $\begin{array}{c}\text { With } \\
\text { Lenkoaggl. }\end{array}$ \\
\hline Transfused & 50 & 41 & $\frac{9(18 \%)}{2(4 \%)}$ \\
\hline Not Transfused & 50 & 48 & $2(48)$ \\
\hline
\end{tabular}

Table 4. Relation of Volume of Transfused Blood to Percentage of Positivity

\begin{tabular}{|c|c|c|c|}
\hline $\begin{array}{c}\text { Volume of } \\
\text { Transfused } \\
\text { Blood }\end{array}$ & $\begin{array}{l}\text { Total No. } \\
\text { of Patients }\end{array}$ & $\begin{array}{l}\text { No. Patients } \\
\text { with } \\
\text { Agglutinins }\end{array}$ & $\begin{array}{l}\text { Per cent of } \\
\text { Positivity }\end{array}$ \\
\hline $\mathrm{cc}$ & 51 & 2 & 3.9 \\
\hline $1 \sim 2000$ & 14 & 1 & 7.1 \\
\hline $2001 \sim 4000$ & 7 & 3 & 42.8 \\
\hline $4001 \sim 6000$ & 6 & 3 & 50.1 \\
\hline $\begin{array}{c}\text { Morethan } \\
6001\end{array}$ & 4 & 2 & 50.0 \\
\hline
\end{tabular}

退院迄陽性を示していた。顆粒球減少症について は４例経験したが，いずれも陰性であつた。なお いずれも発病後 4 日以上経過した症例である。そ の他鉄欠元性貧血16例，パン于症候群 3 例，再生 不良性貧血18例，先天性及び後天性溶血性貧血各 1 例, 巨赤芽球性貧血 2 例, 赤白血病 2 例, 赤血 球增加症 2 例, 慢性白血球減少 3 例, 血管性紫斑 病 2 例について検索したが，いずれも陰性であつ た.

\section{ii）瞳原病}

播種性紅斑性狼瘡 5 例中 2 例に陽性を認わた が，1例は非輸血例であり，他 1 例は $1,800 \mathrm{cc} の$ 輸血を受けている.いずれも白血球凝集素と L.E. 細胞を同㭙に検索して経過をみたが，両者の陽性 は平行しない，強皮症 1 例は陰性であつた。

iii）悪性腫㾤

悪性リンパ腫 4 例币 1 例に陽性を認めたが，非 輸血例である。滰 2 洌中 1 例に陽性を認めたが，

$5,200 \operatorname{cc} の$ 輸血を受けている.

iv）消化器疾㭧

胃漬瘰 2 例中 1 例，望演性大腸炎 1 例に陽性を 認めたがそれぞれ 4,500cc，3,000ccの翰血例 である。

v）腎疾患
慢性腎炎 4 例，いずれも瀕回の交換輸血を受け ているが，その1例に陽性を認めた。この例は 1,700cc輸血時には陰性であつたが，4,400cc輸 血後陽性となつた例である。

vi）その他の疾患

ビールス性肺炎, ヒステリー, 肝硬変, 胸膜 炎，伝染性単核症各 1 例について検索したが，い ずれも陰性であつた。

b) 陽性率と輸血との関係

白血球凝集素の陽性率を, 輸血群, 非輸血群の 2 例に分けて比輘してみると, 輸血群では50例中 9 例 $(18 \%)$ に, 非輸血群では50例中 2 例 ( $4 \%)$ に陽性を認め, 輸血群に陽性率が高く, 両群の間 には推計学的に有意の差を認める. 更に翰血量と 陽性摔との関係をみると，例数が少ないため統計 的処理は無理であるが, 輸血量の増加と共に陽性 率が高くなる傾向を示し，特に $2,000 \mathrm{cc}$ 以上の輸 血例ではその傾向が著明である。

c) 白血球数との関係

陽性例の白血球数を輸血, 非輸血 2 群に分けて みると，喻血陽性例の白血球数は 1,800 から 11,800 の間に分布しているが，非輸血陽性例 2 例では 3,600，4,000であつた。

\section{III 考 案}

白血球凝集素が証明された場合，それがいかな る抗体であるかが問題となる。すなわち，白血球 に対する自家抗体, 同種抗体, 更に薬物による顆 粒球減少症の場合には Miescher のいわゆるア レルギー抗体が白血球凝集素として証明される可 能性がある。従つて,

1）各種疾患別に証明された白血球凝集素が同 種抗体，自家抗体のいずれであるか。

2）輸血との関係

3）白血球型

4）陽性例と白血球数との関係 について従来の交献を総括しつっ考案してみた w.

1）各種疾患について

i）血液疾患 


\section{a) 白血病}

Dausset ${ }^{2)}$, Goudismit 花び Van Loghem ${ }^{5)}$ がいずれも非白血性白血病について初めて報告し たが，自家抗体，同種抗体のいずれか不明であ る. Miescher'6) は，自家抗体と輸血による同種 抗体との区別が困難であることを强調している が，白血病の場合には自家抗体が高率に証明され る可能性があると唱えている。すなわち，白血病 細胞が生体に対して異物として働き，をれに対す る自家抗体ができると考えたが，まだ去分には証 明されていない，Killman7) は，急性单球性白 血病の 1 例において白血球凝集素を経過をおつて 観察し，白血性の時期に注証明されないが，非白 血性の時期には証明されたと報告し，輸血による ものではないので自家抗体と考えている，その後 \& Killman ${ }^{8)}$ \&. 2 例の白血病について報告し, 1 例怯非翰血例で明らかに自家抗体であり，他の 1 例は. 2 回の輸血を受けてはいるが，自家凝集を 認め, 凝集価が高く, プレドニソロンにより白血 性となつた点から自家抗体であろうと報告してい る. 一方 Payne ${ }^{9)}$ は, 各種白血病77例中10例に 陽性を諗るたが，その中非輸血例は 1 例のみであ つたと報告し，輸血による影響を強調している。

この様に白血病の場合には，自家抗体，同種抗 体の両者が関与することが多く，その区別には慎 重でなければならない，私の経験した急性骨髄性 2 例, 慢性骨髄性 1 例はいずれも頻回輸血例であ るが，うち急性の 1 例は入院時陰性で, 輸血量の 增加と共に陽性となり, 大量のプレドニソロン使 用にもかかわらず常に陽性であつた点から，榆血 による同種坑体と考えられる。他2例については 明らかでない。

b) 顆粒球減少症

Moeschlin1)のピラミトンによる䫐粒球減少 症についての報告以来, 本症についての報告が最 も多、。 すなわち，ピラミドン，サルファ都, 水 銀利尿剂, サイオユラシル等による本症に白血球 凝集素が証明されている。しかし，本症に証明さ れる凝集素は，原因上なる薬物の投与後にのみ一
時的に証明され，被検血清を不活化しなくとも凝 集を認める点で通常の白血球凝集素々性䁈を買に するので6)，それを区别するために Miescher はアレルギー抗体と名付けている。原因楽物の種 類により差があるかもしれないが，蓧物中止後 4 乃至 5 日経過すると白血球凝集は認められなくな る6). 更に発病後一定時間経過していて凝集が認 められない場合には，原因薬物の少量投与後に検 索するが，投与後 8 時間には㠜集が強く，24時間 後にはかなり弱くなり，60時閏後には証明されに くいという6)，私の経験した 4 例はいずれも発病 後4日以上を経過しているために証明できなかつ たのであろう。

\section{c）再生不良性賀血}

本症の多くの場合には病因不明であるが，免疫 血液学の進步と共に本症の病因に侁疫学的機椣 が関与するのではないかと考えられ，三血球成分 に対する抗体の検索が行なわれた. Dausset ${ }^{10)}$ は，三血球成分に刘する抗体を同時に証明し得た 症例を初めて報告したが，いずれも榆血列であ り，それらの抗体が自家抗体，同種抗体のいずれ であるかは不明である. Miescher ${ }^{6)}$ は, 白血球 凝集素索証明し得た症例を報告しているが，赤血 球，血小板に刘する抗体は証明できず，しかも白 血球凝集素も輸血による同種抗体であろうとして

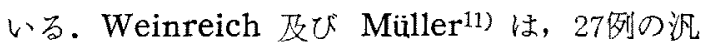

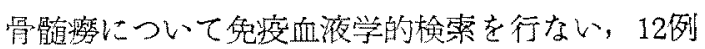
に白血球凝集素証明している。しかし，うち10 例は輸血例， 1 例はピラミドン投与後にのみ証明 され，残る 1 例は，非輸血例で赤血球及び血小板 に対する抗体も同时に証明されたが，骨髄け過形 成で脾腫翟め, 本邦で日常みられる再生不良性

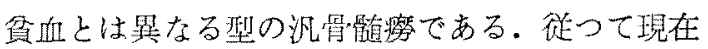
迄本症に証明されている白血球㠜集素け, 輸血に よる同種抗体と考えられ，明らかに自蒙抗体と考 えられる凝集素忖証明されていない。私の経験し た18例は，いずれも大量輸血例であるがい゙ずれ にも白血球凝集素を証明できなかつた。

d) 後天性溶血性贫血 
本症において赤血球に詨する抗体が生ずるのと 同様の機序により, 白血球抗体を生ずる可能性が ある。本症に白血球凝集素を証明し得た例は少な くなく5)9， しかも輸血を受计て㧍らず明らかに 自家抗体上考えられる例名報告されている。特に 寒椧自家抗体に上る本症では，しばしば自血球減 少をともない目血球凝集意が証明されるが，Miescher6) は，赤血球㠜集により自血球も共に凝集 され誤つて白血球凝集素陽性とされる可能性があ り，注意すべきであるといつている．この点でも 擬集を調べる際に，白血球をなるべく純粋に分離 して健用すべきである。

私の経驗した後天゙性溶血性盆血の1例では，白 血球凝集素を証明できなかつた。

e）その他の血液疾患

発作性夜閒血色素尿症2》，低色素性督血2)，血 小板減少性紫玟病6)，慢性白血球減少症6》等に証 明したとの報告がみられるが，その多くは輸血に よる同種抗体と考えられる。私の経験した血小板 減少性紫玟病の 1 例も輸血前陰性で, $3,500 \mathrm{cc}$ 輸 血後に初めて陽性となつたもので，輸血による同 種抗体と考えられる。

ii）膠原病

主として播種性紅斑性狼瘡5112)，Felty 症候群 12)について陽性例が報告されている．特に播種性 紅斑性狼瘖には，白血球核物質，赤血球，血小 板，トロンボブラスチン等に対する自家抗体が証 明されているが，白血球凝集素陽性例の報告も少 なくない，抗白血球齐抗体が白血球に作用して白 血球凝集をおこすのではないかと考えられたが， 吸攻試験の結果白血球凝集素とは異なるものであ ることが明らかになつた。本症の多数例について

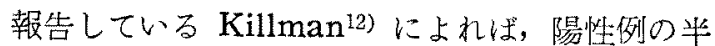
数は非輸血例で自家抗体と考えられたが, L.E.因 子とは関係がないと報告している。私は，輸血， 非輸血各 1 例に陽性を琶めているが， L.E. 細胞 の消長とは平行していない。

iii ) 悪性腫序

琹性腫嗙としては，骨䯣腫13)，ホジキン病2，
リンパ药芽腫2等について陽性例つ報告があり， Moeschlin ${ }^{13)}$ はこれら腫演の際に生ずる Paraprotein がハプテンとなつて抗体を産生するので あろうと推定しているが証明されてはいない，私 は悪性リンパ腫，胃癌の各 1 例に陽性を認めた。 前者は非輸血例で自芜抗体と考えられるが，後者 は 5,200ccの大量輸血例であるが，輸血前に検萦 を行なつていないので自家抗体，同種抗体のいず れかは不明である.な招胃癌についてはこれ迄報 告がない。

iv）消化器疾患

消化器疾患について陽性挒の報告は殆どみられ ない，私は，従来報告のない胃潰㾥，漬瘍性大 腸炎の各 1 例に陽性を認めた。いずれもそれぞれ 4,500cc， 3,000ccの輸血を受汁ており，輸血に よる同種抗体の可能性が強い.

v) 腎疾患

腎炎が自家免疫性疾患であることはよく知られ ているが，白血球凝集素を認めた報告はない，慢 性腎炎の 1 例に陽性を認めたが，本例は $1,700 \mathrm{cc}$ 輸血後には㓌性であつたが， $4,400 \mathrm{cC}$ 輸血後には 陽性となり，輸血による同種抗体と考えられる。 なお同時期に教室の高田201は，溶血素を証明して おり，濒回の輸血により各種の抗体の産生が高ま ることを示す1例として興味がある。

vi）その他の疾患

ビールス性肺炎13)，伝染性単校症13)，慢性脾結 楚13)，慢性脾バング等に陽性例の報告があり， Moeschlin ${ }^{13)}$ は，ビールス又は細菌がハブテンと して作用し，莯体を座生するのであるうと考えて いる.ビールス性肺炎，伝染性単核症の各 1 例に ついて検渠したが，いずれも陰性であつた。

以上白血球筑集素陽性の疾患について考察した が，証明された抗体が，自家抗体，同種抗体のい ずれであるかを区別するのは難かしい，輸血の辰 往がなく，自家白血球凝集の強い場合には自家抗 体といい得るが，自芜抗体は必すしも自家白血球 凝集を示さないとの報告もある。両抗体を区別す る時にはその他コーチゾン製剤治療による凝集 
素価と白血球数との変動，洗涤自家白血球との凝 集の有無等が参若になると思われる8が，Van

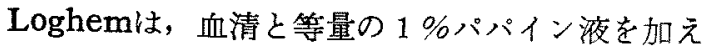
ると同種抗体の場合には凝集がおこらないので両 抗体を区別できると報告している。

2) 輸血との関係

從来報告のない二，三の疾患に陽性例を認め， しかもそれらがいすれも輸血例であることから， 頻回大量の輸血が抗体産生に何らかの影響を及淉 すのではないかと考え，輸血と陽性率との関係を 検討した。輸血例に明らかに陽性率が高く、し か子輸血量が多い程陽性摔が高くなる傾向を認め た. Dausset ${ }^{14)}$ は，白血球凝集素陽性例60例中 の $90 \%$ が瀕回の輸血を受けていることを示して， 陽性率と輸血が密接な関係にあることを示陵し，

Payne9) \&陽性例38例中非輸血例は 4 例にすぎ ず，輸血回数が多い程陽性率の高くなる傾向を示 すことを明らかにし，Killman ${ }^{12)} は ，$ 輸血陽性 例について白血球凝集素価の消長を調べて, 輸血 中に凝集素価が上昇することを認めている。

Payne9) は，徒来報告のない数種の疾患に陽 性例を認めて，その大部分が輸血例であることか ら輸血によつて陽性を示す疾患の範围が広くなる 可能性のあることを示しているが，私もこれ迄報 告のない胃癌, 胃潰瘍, 潰瘍性大腸炎, 慢性腎炎 に陽性例を認め，それらがいずれも大量輸血例で あることは興味がある。

つぎに疾患によつて輪血による抗体産生に差が あるかどうかを考察してみよう。一般に抗体産生 は, 宿主と抗原の条件, 宿主と抗原が接する頻度 により決定される.同一抗原で同回数感作しても 個体により抗体産生の異なることはよく知られて おり, 更に病的状態では正常の時上は異なる態度 を示す可能性がある. Larson及び Tomlinson ${ }^{15)}$ は，肺炎球菌多棓類を使用して白血病及び悪性り ンパ腫患者における抗体産生を研究し, 未治療の 急性白血病の場合に注抗体産生が增加している が，慢性リンパ性白血病では。逆に低下し，悪性リ ンパ腫では正常と同様であつたと報告している。
従つて輸血による抗体産生にも疾患により差のあ る可能性があるが，現在迄その点に関する報告は ない。

最近輸血の副作用と白血球凝集素との関係が漸 次明らかになつてきた。Payne16) は, 陽性例32 例中13例に副作用を認めたが，副作用と凝集素価 は必ずしも相関しないと報告しているが，その後 副作用は白血球凝集甞価の高い例に多く，その場 合白血球を除いて輸血すると副作用を防止できる 点から両者の関係が密接であることが明らかとな つた。

3）白血球型

赤血球に関して A B O同型の輸血を行なつても 白血球に対する同種抗体が産生される点から，白 血球には赤血球と異なる型があるのではないかと 考えられ，白血球型に関する研究が行なわれる滕 になつた。

Moeschlin 及び Schmid ${ }^{3)}$ は，30例の患者に つてその血清と白血球との間に瀕回の交文試験 を行なつて，ABO不適合の組合せの $34 \%$, 適 合の組合せの $5 \%$ に白血球凝集を認め, Dausset は，白血球凝集素陽性例 21 例の血清と 12 人の白血 球との間で交皮試験を行ない，白血球には多く の型の存在することを報告して赤血球と異なる型 の存在を示惨している17)。しかし, Killman ${ }^{18)}$ は, 50例の正常人血清と 7 人の $\mathrm{O}$ 型白血球との交 叉試験では，全例㠜集を認めなかつたと報告して いる. Wichels 及び Lampe ${ }^{19)}$ は，A型の白血 病患者白血球を使用して $\mathrm{A}$ 抗原の存在を明らかに し，その後の研究により白血球にもA又はB抗原 を有するもののあることが確実となり,Ballowitz は，白血球にも $\mathrm{Rh}$ 抗原が存在するのではないか と報告している。結局現在まだ充分に証明されて はいないが，白血球には赤血球と異なる型が存在 するであろうことは明らかである。

4) 陽性例と白血球数との関係

白血球凝集素陽性例でも，それが自家抗体と考 えられる場合には白血球減少，好中球娍少を譛め る例が多いが，輸血による同種抗体の場合には不 定であるとの報告が多い9)12)。私の陽性例でも同 
様の傾向を示しているが，大量の輸血を受けてい た急性骨髄性白血病の 1 例では凝集素陽性であり ながら11,800と白血球增多を示していたのは興味 樑い。

\section{IV 結 論}

血液疾患主とする各種内科疾患100例につい て，Dausset 法に占り白血球㠜集素省检索して 次の結果を得た。

（1） 11例（11\%）に陽性主認めた。

（2）陽性例は明ら加に輸血群に多く，輸血量 が多い型陽性摔の高くなる傾问がある。

（3）非輸血陽性例は，播種性紅斑性狼瘡，覀 性リンパ腫の各 1 例であり，輸血陽性例は，急性 骨䯣性白血病 2 例，慢性省䯣性白血病，血小板減 少性紫玟病, 播種性紅玟性狼痕, 胃癌, 胃漬垣, 實湟性大腸炎，慢性腎炎の各1例で，後 4 者につ いては従来報告がみられない。

（4）非輸血陽性例では白血球減少を認めた が，輸血陽性例では不定である。

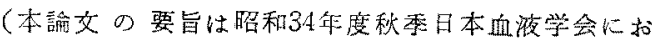
いて報告した）。

\section{文献}

1) Moeschlin, S. \& Wagner, K.: Acta Haemat. $8: 29,1952$. - 2) Dausset, J. et al: BIood. 9 : 696, 1954. - 3) Moeschlin, S. \& Schmid; E.: Acta Haemat. 11 : 241, 1954. 4) Kimura, E.: Jap. J. Physiol. $3: 25,1952$. - 5) Goudsmit, R. \& Van Loghem, J.J.: Vox Sanguin. $3: 58$, 1953. - 6) Miescher, P.: Ergeb. Inn. Med. u. Kinderheilkunde. 7 : 170, 1956. - 7) Killman, S-Å.: Acta Haemat. 17: 360, 1957. - 8) Killman, S-Å.: Acta med. Scand. 163 : 207, 1959. - 9) Payne, R. Arch. Int. Med. 99 : 587, 1957. - 10) Dausset. J. et al: Rev. Hematol. 8 : 316, 1953. -11) Müller, W. \& Weinreich, J.: Klin. Wochschr. 34 : 505, 1956. -12) Killman, S-Å.: Acta med. Scand. 163 : 449, 1959. - 13) Moeschlin, S.: Acta Haemat. $18: 13,1957 .-14$ ) Dausset, J.: Vox Sang. 4 : 190, 1954. - 15) Larson, D.L. \& Tomlinson, L.J.: J. Clin. Invest. 32: 317 , 1953. - 16) Payne, R.: Vox Sang. 2 : 233, 1957. - 17) Cited from Miescher, P. \& Vorlaender, K.O.: Immunopathologie in Klinik u. Forschung. Georg Thieme. Stuttgart. 1957. 18) Killman, S-Å.: Acta med. Scand. 163: $445,1959 . \quad$ - 19) Wichels, P. \& Lampe, W.: Klin. Wochschr. 1741, 1928, 一 20) 高田: 滪応 医学, 37 : 762, 1960 . 